\title{
A STUDY ON JOB SATISFACTION AND INSTITUTIONAL COMMITMENT AMONG HIGH SCHOOL TEACHERS WITH SPECIAL REFERENCE TO IRINJALAKUDA MUNICIPALITY THRISSUR KERALA
}

\author{
Remya. S \\ Assistant Professor, St Joseph’s College (Autonomous) Irinjalakuda
}

\begin{abstract}
Job satisfaction probably is the most widely studied variable in organisational behaviour. Though the study of job satisfaction is common in many organisations, it has become a serious problem in the management of educational institutions. Teachers are the pillars of our nation. A teacher who is satisfied with their job will be in a position to fulfil the educational objectives and national goals. A dissatisfied teacher is not only a loss to their self but also to the entire institution. They cannot perform their duties well. The present study was an attempt to analyse or assess the level of job satisfaction and institutional commitment of Government, Aided and Unaided high school teachers in Irinjalakuda municipality. A sample of 60 respondents was selected (20 from Government, Aided and Unaided schools) using non-probability sampling technique. Questionnaire is used to collect primary data. The major objectives were to examine the level of job satisfaction and institutional commitment of teachers, to identify the factors influencing job satisfaction and to test the association between type of management, monthly income and subject taught with job satisfaction. The collected data was analysed using Percentage Analysis, Weighted Average Score Ranking, Likert Scale and Chi- Square Test.
\end{abstract}

Keywords: Job Satisfaction-Institutional commitment

\section{INTRODUCTION}

Nothing is more important or more valuable gift to the nation than educating its youth. Education had always been given a very significant place in all civilized nations. India has been one of the pioneers in education. The respect and importance, that are given to education and educator still remain unparalleled in India and find their genesis in the history of the country evolution of education here. Education brings about a change in an individual, a society and also in the entire nation. More over economic, social and political development of a nation is possible through education.

The performance of teachers is very crucial in the field of education. Teachers are the heart and soul of education. According to the American commission on Teacher education (1974), "The quality of a nation depends upon the quality of its citizens and the quality of its citizens depends upon the quality of their teachers". Teachers play an inevitable role not as a mere transmitter of knowledge and culture but as a change agent. Teachers prepare the next generation and it is the level of their commitment, devotion, and dedication that determine the future society.

Satisfaction is an essential factor in any profession. Unless a man is satisfied with his job, it is very difficult for him to carry on his duties honestly and efficiently. Job satisfaction is the result of attitude possessed by an employee, which is the result of many specific attitudes which comes from 3 areas,

1. Specific job factor

2. Individual characteristics

3. Group relationship outside the job.

Sweeny and Mcfarln (2002) defined Job Satisfaction as the result of psychological comparison process of the extent to which various aspects of their job measure up to what they desire. Thus, the larger the gap between 'what employees have' and 'what they want' from their job, the less satisfied the employees are. In other words employees tend to the most satisfied with their job when 'what they have' matches 'what they want'.

Commitment of the employees towards their organisation has received a considerable attention in the field of management and organisational behaviour. Commitment refers to the employee's emotional attachment and the involvement in the organisation. A highly committed person has the feeling that he is working for himself and not for somebody else. As a result, he/ she develop a sense of responsibility and do not require any external drive for his/her job performance.

Thus teacher's performance and commitment is a crucial input in the field of education. In the absence of capable and committed teachers, educational institutions can not develop into potential instrument of national development. 
Vol. 8, Issue 8, August 2021

\section{DOI: 10.17148/IARJSET.2021.8858}

2.STATEMENT OF THE PROBLEM

Involvement and commitment of teachers is purely dependent upon morale, motivation and job satisfaction. In all organisations including schools, motivation and job satisfaction play an important role. In educational institutions, teachers are the key players who ensure achievement of goals and objectives of the organisation and they are key people who mould the students to excel in their career. Teacher's job satisfaction is not only important to the teachers but also important to the students.

\section{SIGNIFICANCE OF THE STUDY}

Education plays an important role in the development of any nation. Hence it is required to give top priority for educational system which is possible mainly through teachers, in whose hands the destiny of our coming generation is placed. The study is important as it will highlight the factors that would enhance job satisfaction of school teachers. Teacher who achieve success in her or his job and whose needs are met in the workplace turns happy who would strive to maintain excellence. The findings of this study will provide academic theoretical, practical and policy implications which can significantly contribute to the body of knowledge in job satisfaction of teachers.

\section{SCOPE OF THE STUDY}

The study is intended to identify and examine the dimensions of job satisfaction of teachers. The theoretical part of the study uses a descriptive method to define the basic concepts of job satisfaction. The empirical part is based on analytical research where the research instrument is presented through structured questionnaire. The analysis is based on the data collected from school teachers of selected schools in Irinjalakuda municipality. The study examines and analyse job satisfaction of randomly selected teachers.

\section{OBJECTIVES OF THE STUDY}

- To identify the factors that influence job satisfaction.

- To examine the level of satisfaction of Government, aided and unaided school teachers.

- To examine the commitment of school teachers towards their school and work assigned.

- To test whether there is any relationship between selected variables and overall job satisfaction of teachers

\section{RESEARCH METHODOLOGY}

Both primary and secondary data are used for the study. Primary data has been collected using questionnaire. Secondary data has been collected from various published sources of information such as books, journals, articles, websites etc.

Research Design

- Population

High school teachers of Government, Aided, and Unaided schools in Irinjalakuda Municipality.

- $\quad$ Sampling Frame

Selected high schools from Government, Aided and Unaided streams in Irinjalakuda Municipality

- $\quad$ Sample Unit

Each teacher of sampling frame.

- $\quad$ Sampling Size

The sample size is 60 .

- $\quad$ Sampling Technique

Non Probability sampling.

- $\quad$ Sampling Method

Judgmental Sampling.

\section{LIMITATIONS OF THE STUDY}

- $\quad$ The present study is based on data collected from Irinjalakuda Municipality. So it cannot be generalized.

- $\quad$ The sample size is restricted to 60 .

- $\quad$ Some of the replies from the respondents may be biased.

\section{LITERATURE REVIEW}

Adenike (2011) in his study entitled 'Organisational Climate as a predictor of employee job satisfaction: evidence from Covenant university' had studied the job satisfaction level of employees in relation to organisational climate in private university i.e. Covenant University,Ota. It was found from the study that there was no significant job satisfaction among employees.Rasouli et al. (2011) in his study entitled 'Relationship between hardiness and job satisfaction \& stress among staff and faculty members of Islamic Azad university of Mahabad' had examined the relationship between hardiness and job satisfaction in Islamic Azad University in Mahabad, Iran through Likert scale, T-test and regression test and found that there is positive relationship between hardiness and job satisfaction level of staff.Mehr et al. (2012) in his study entitled 'Relationship between job satisfaction and organisational culture in staffs and experts of physical education offices of Mazandaran Province' had examined the relationship between organisational culture and job satisfaction. He found that organisation culture was not significant for job satisfaction.Kautonen \& Akola (2013) in his study entitled 'Determinants of job satisfaction for salaried 


\title{
International Advanced Research Journal in Science, Engineering and Technology
}

\author{
Vol. 8, Issue 8, August 2021
}

\section{DOI: 10.17148/IARJSET.2021.8858}

and self employed professionals in Finland' had said about the determinants of job satisfaction. He found that self employed were more satisfied as compared to salaried person. Chahal (2013) in her research entitled 'Job Satisfaction among Bank Employees: An Analysis of the Contributing Variables towards Job Satisfaction' had examined the variables that contribute to job satisfaction. She found that working environment, performance appraisal technique, colleague's relationship, safety provisions were factors which contribute toward job satisfaction but at the same time nature of work, salary and incentives, working hours, training and development of employees and frequent transfers, dislocation of these factors causes most dissatisfaction among the employees.

Table 1

Institutional commitment of Government School Teachers

\begin{tabular}{|c|c|c|c|c|c|c|c|c|c|c|c|}
\hline \multirow[t]{2}{*}{ No } & & \multicolumn{2}{|c|}{ SA } & \multicolumn{2}{|c|}{$\mathbf{A}$} & \multicolumn{2}{|c|}{$\mathbf{N}$} & \multicolumn{2}{|c|}{ DA } & \multicolumn{2}{|c|}{ SDA } \\
\hline & & No & $\mathbf{W}$ & \begin{tabular}{|l|} 
No \\
\end{tabular} & $\mathbf{W}$ & No & $\mathbf{W}$ & No & $\mathbf{W}$ & No & $\mathbf{W}$ \\
\hline 1 & $\begin{array}{l}\text { I devote more time and } \\
\text { effort to make my school } \\
\text { more successful }\end{array}$ & 7 & 35 & 4 & 16 & 7 & 21 & 2 & 4 & 0 & 0 \\
\hline 2 & $\begin{array}{l}\text { I would accept any type } \\
\text { of job assigned to me } \\
\text { happily }\end{array}$ & 6 & 30 & 3 & 12 & 7 & 21 & 3 & 6 & 1 & 1 \\
\hline 3 & $\begin{array}{l}\text { I find the values of mine } \\
\text { and school similar }\end{array}$ & 3 & 15 & 5 & 20 & 10 & 30 & 2 & 4 & 0 & 0 \\
\hline 4 & $\begin{array}{l}\text { I am proud to tell others } \\
\text { that I am part of this } \\
\text { school }\end{array}$ & 12 & 60 & 6 & 24 & 2 & 6 & 0 & 0 & 0 & 0 \\
\hline 5 & $\begin{array}{l}\text { This school really } \\
\text { inspires me to find the } \\
\text { best in me }\end{array}$ & 8 & 40 & 2 & 8 & 9 & 27 & 1 & 2 & 0 & 0 \\
\hline 6 & $\begin{array}{l}\text { I really care about the } \\
\text { future and goodwill of } \\
\text { my school }\end{array}$ & 9 & 45 & 5 & 20 & 5 & 15 & 1 & 2 & 0 & 0 \\
\hline 7 & $\begin{array}{l}\text { For me this is the best } \\
\text { institution to work for }\end{array}$ & 11 & 55 & 2 & 8 & 6 & 18 & 1 & 2 & 0 & 0 \\
\hline
\end{tabular}

(SA - Strongly Agree, A- Agree, N- Neutral, DA- Disagree, SDA- Strongly Disagree)

\begin{tabular}{|l|c|c|c|}
\hline & Total Score & Mean & Rank \\
\hline $\begin{array}{l}\text { I devote more time and effort to make my school more } \\
\text { successful }\end{array}$ & 76 & 3.8 & 5 \\
\hline I would accept any type of job assigned to me happily & 70 & 3.5 & 6 \\
\hline I find the values of mine and school similar & 69 & 3.45 & 7 \\
\hline I am proud to tell others that I am part of this school & 90 & 4.5 & 1 \\
\hline This school really inspires me to find the best in me & 77 & 3.85 & 4 \\
\hline I really care about the future and goodwill of my school & 82 & 4.1 & 3 \\
\hline For me this is the best institution to work for & 83 & 4.15 & 2 \\
\hline
\end{tabular}

From the above table it can be seen that respondents are mostly agreed to the fact that I am proud to tell others that I am part of this school, then For me this is the best institution to work for, then I really care about the future and goodwill of my school, then This school really inspires me to find the best in me, then I devote more time and effort to make my school more successful, then I would accept any type of job assigned to me happily and least agreed to the fact that I find the values of mine and school similar.

Table 2

Institutional commitment of Aided School Teachers

\begin{tabular}{|c|c|c|c|c|c|c|c|c|c|c|c|}
\hline \multirow[t]{2}{*}{ No } & & \multicolumn{2}{|c|}{$\mathbf{S A}$} & \multicolumn{2}{|c|}{$\mathbf{A}$} & \multicolumn{2}{|c|}{$\mathbf{N}$} & \multicolumn{2}{|c|}{ DA } & \multicolumn{2}{|c|}{ SDA } \\
\hline & & No & W & No & $\mathbf{W}$ & No & W & No & W & No & $\mathbf{W}$ \\
\hline 1 & $\begin{array}{l}\text { I devote more time } \\
\text { and effort to make } \\
\text { my school more } \\
\text { successful }\end{array}$ & 3 & 15 & 6 & 24 & 9 & 27 & 1 & 2 & 1 & 1 \\
\hline 2 & $\begin{array}{l}\text { I would accept any } \\
\text { type of job assigned } \\
\text { to me happily }\end{array}$ & 2 & 10 & 1 & 4 & 10 & 30 & 4 & 8 & 3 & 3 \\
\hline
\end{tabular}


Vol. 8, Issue 8, August 2021

DOI: 10.17148/IARJSET.2021.8858

\begin{tabular}{|l|l|l|l|l|l|l|l|l|l|c|c|}
\hline 3 & $\begin{array}{l}\text { I find the values of } \\
\text { mine and school } \\
\text { similar }\end{array}$ & 4 & 20 & 3 & 12 & 10 & 30 & 2 & 4 & 1 & 1 \\
\hline 4 & $\begin{array}{l}\text { I am proud to tell } \\
\text { others that I am part } \\
\text { of this school }\end{array}$ & 2 & 10 & 3 & 12 & 10 & 30 & 3 & 6 & 2 & 2 \\
\hline 5 & $\begin{array}{l}\text { This school really } \\
\text { inspires me to find } \\
\text { the best in me }\end{array}$ & 4 & 20 & 5 & 20 & 6 & 18 & 4 & 8 & 1 & 1 \\
\hline 6 & $\begin{array}{l}\text { Ireally care about the } \\
\text { future and goodwill } \\
\text { of my school }\end{array}$ & 6 & 35 & 4 & 16 & 5 & 15 & 4 & 8 & 1 & 1 \\
\hline 7 & $\begin{array}{l}\text { For me this is the best } \\
\text { institution to work } \\
\text { for }\end{array}$ & 3 & 15 & 3 & 12 & 9 & 27 & 3 & 6 & 2 & 2 \\
\hline
\end{tabular}

(SA - Strongly Agree, A- Agree, N- Neutral, DA- Disagree, SDA- Strongly Disagree)

\begin{tabular}{|l|c|c|c|}
\hline & Total Score & Mean & Rank \\
\hline $\begin{array}{l}\text { I devote more time and effort to make my school more } \\
\text { successful }\end{array}$ & 69 & 3.45 & 2 \\
\hline I would accept any type of job assigned to me happily & 55 & 2.75 & 7 \\
\hline I find the values of mine and school similar & 67 & 3.35 & 3.5 \\
\hline I am proud to tell others that I am part of this school & 60 & 3 & 6 \\
\hline This school really inspires me to find the best in me & 67 & 3.35 & 3.5 \\
\hline I really care about the future and goodwill of my school & 75 & 3.75 & 1 \\
\hline For me this is the best institution to work for & 62 & 3.1 & 5 \\
\hline
\end{tabular}

From the above table it can be seen that respondents are mostly agreed to the fact that I really care about the future and goodwill of my school, then I devote more time and effort to make my school more successful, then I find the values of mine and school similar and This school really inspires me to find the best in me, then For me this is the best institution to work for, then I am proud to tell others that I am part of this school and least agreed to the fact that I would accept any type of job assigned to me happily.

Table 3

Institutional commitment of Unaided School Teachers

\begin{tabular}{|c|c|c|c|c|c|c|c|c|c|c|c|}
\hline \multirow[t]{2}{*}{ No } & & \multicolumn{2}{|c|}{ SA } & \multicolumn{2}{|c|}{$\mathbf{A}$} & \multicolumn{2}{|c|}{$\mathbf{N}$} & \multicolumn{2}{|c|}{ DA } & \multicolumn{2}{|c|}{ SDA } \\
\hline & & No & W & No & W & No & W & No & W & No & $\mathbf{W}$ \\
\hline 1 & $\begin{array}{l}\text { I devote more time } \\
\text { and effort to make } \\
\text { my school more } \\
\text { successful }\end{array}$ & 4 & 20 & 3 & 12 & 11 & 33 & 1 & 2 & 1 & 1 \\
\hline 2 & $\begin{array}{l}\text { I would accept any } \\
\text { type of job assigned } \\
\text { to me happily }\end{array}$ & 5 & 25 & 5 & 20 & 7 & 21 & 2 & 4 & 1 & 1 \\
\hline 3 & $\begin{array}{l}\text { I find the values of } \\
\text { mine and school } \\
\text { similar }\end{array}$ & 3 & 15 & 4 & 16 & 12 & 36 & 1 & 2 & 0 & 0 \\
\hline 4 & $\begin{array}{l}\text { I am proud to tell } \\
\text { others that I am part } \\
\text { of this school }\end{array}$ & 9 & 45 & 5 & 20 & 5 & 15 & 1 & 2 & 0 & 0 \\
\hline 5 & $\begin{array}{l}\text { This school really } \\
\text { inspires me to find } \\
\text { the best in me }\end{array}$ & 9 & 45 & 6 & 24 & 2 & 6 & 2 & 4 & 1 & 1 \\
\hline 6 & $\begin{array}{l}\text { I really care about } \\
\text { the future and } \\
\text { goodwill of my } \\
\text { school }\end{array}$ & 10 & 50 & 5 & 20 & 4 & 12 & 1 & 2 & 0 & 0 \\
\hline 7 & $\begin{array}{l}\text { For me this is the } \\
\text { best institution to } \\
\text { work for }\end{array}$ & 6 & 30 & 4 & 16 & 7 & 21 & 2 & 4 & 1 & 1 \\
\hline
\end{tabular}




\section{International Advanced Research Journal in Science, Engineering and Technology}

Vol. 8, Issue 8, August 2021

DOI: 10.17148/IARJSET.2021.8858

(SA - Strongly Agree, A- Agree, N- Neutral, DA- Disagree, SDA- Strongly Disagree)

\begin{tabular}{|c|c|c|c|}
\hline & Total Score & Mean & Rank \\
\hline $\begin{array}{l}\text { I devote more time and effort to make my school more } \\
\text { successful }\end{array}$ & 68 & 3.4 & 7 \\
\hline I would accept any type of job assigned to me happily & 71 & 3.55 & 5 \\
\hline I find the values of mine and school similar & 69 & 3.45 & 6 \\
\hline I am proud to tell others that I am part of this school & 82 & 4.1 & 2 \\
\hline This school really inspires me to find the best in me & 80 & 4 & 3 \\
\hline I really care about the future and goodwill of my school & 84 & 4.2 & 1 \\
\hline For me this is the best institution to work for & 72 & 3.6 & 4 \\
\hline
\end{tabular}

From the above table it can be seen that respondents are mostly agreed to the fact that I really care about the future and goodwill of my school, then I am proud to tell others that I am part of this school, then This school really inspires me to find the best in me, then For me this is the best institution to work for, then I would accept any type of job assigned to me happily, then I find the values of mine and school similar least agreed to the fact that I devote more time and effort to make my school more successful.

\section{Chi- Square Test}

Chi- square test is a statistical test commonly used to compare observed data with data one would expect to obtain according to a specific hypothesis. Random data must be used in calculating chi-square static, raw and mutually exclusive drawn from independent variable and drawn from a large enough sample. It was developed by Prof. Karl Pearson in 1990 and it is one of the simplest and most widely used non- parametric test in statistical work. Chi- square is the sum of the squared difference between observed $(\mathrm{O})$ and expected $(\mathrm{E})$ data, divided by the expected data in all possible categories.

It is represented as;

$(\mathrm{O}-\mathrm{E})^{2} / \mathrm{E}$

$\mathrm{O}=$ Observed frequencies

$\mathrm{E}=$ Expected frequencies

1. Testing the association between the type of management and satisfaction level.

H0: There is no association between type of management and level of satisfaction

H1: There is association between type of management and level of satisfaction

Table 4

\begin{tabular}{|c|c|c|c|c|}
\hline & Government & Aided & Unaided & Total \\
\hline Satisfied & 14 & 7 & 2 & $\mathbf{2 3}$ \\
\hline Neutral & 4 & 12 & 11 & $\mathbf{2 7}$ \\
\hline Dissatisfied & 2 & 1 & 7 & $\mathbf{1 0}$ \\
\hline Total & $\mathbf{2 0}$ & $\mathbf{2 0}$ & $\mathbf{2 0}$ & $\mathbf{6 0}$ \\
\hline
\end{tabular}

Degree of freedom $=(\mathrm{r}-1)(\mathrm{c}-1)$

$$
=(3-1)(3-1)=4
$$

The table value at $5 \%$ level of significance for degree of freedom 4 is 9.488

Table 5

\begin{tabular}{|c|c|c|c|c|}
\hline $\mathbf{O}$ & $\mathbf{E}$ & $\mathbf{( O - E )}$ & $(\mathbf{O}-\mathbf{E})^{\mathbf{2}}$ & $(\mathbf{O}-\mathbf{E})^{\mathbf{2}} / \mathbf{E}$ \\
\hline 14 & 8 & 6 & 36 & 4.5 \\
\hline 6 & 12 & -6 & 36 & 3 \\
\hline 7 & 8 & -1 & 1 & 0.125 \\
\hline 12 & 9 & 3 & 9 & 1 \\
\hline 3 & 11 & -8 & 36 & 3 \\
\hline 18 & 12 & 6 & & $\mathbf{1 7 . 4 5}$ \\
\hline \multicolumn{7}{|c}{ Calculated Value } \\
\hline
\end{tabular}

Calculated value (17.45) is more than table value (9.488). Therefore we reject null hypothesis.

There is association between the type of management and overall job satisfaction of teachers.

\section{Testing the association between monthly income and satisfaction level}

H0: There is no association between monthly income and level of satisfaction.

H1: There is association between monthly income and level of satisfaction. 
Vol. 8, Issue 8, August 2021

DOI: $10.17148 /$ IARJSET.2021.8858

Table 6

\begin{tabular}{|c|c|c|c|c|}
\hline & $\mathbf{2 0 0 0 0}$ to 30000 & 30000 to 40000 & More than 40000 & Total \\
\hline Satisfied & 2 & 5 & 16 & $\mathbf{2 3}$ \\
\hline Neutral & 10 & 11 & 6 & $\mathbf{2 7}$ \\
\hline Dissatisfied & 6 & 3 & 1 & $\mathbf{1 0}$ \\
\hline Total & $\mathbf{1 8}$ & $\mathbf{1 9}$ & $\mathbf{2 3}$ & $\mathbf{6 0}$ \\
\hline
\end{tabular}

Degree of freedom $=(\mathrm{r}-1)(\mathrm{c}-1)$

$$
=(3-1)(3-1)=4
$$

The table value at $5 \%$ level of significance for degree of freedom 4 is 9.488

Table 7

\begin{tabular}{|c|c|c|c|c|}
\hline $\mathbf{O}$ & $\mathbf{E}$ & $\mathbf{( O - E )}$ & $(\mathbf{O}-\mathbf{E})^{\mathbf{2}}$ & $(\mathbf{O}-\mathbf{E})^{\mathbf{2}} / \mathbf{E}$ \\
\hline 2 & 7 & -5 & 25 & 3.5 \\
\hline 16 & 11 & 5 & 25 & 2.2 \\
\hline 5 & 7 & -2 & 4 & 0.57 \\
\hline 14 & 12 & 2 & 4 & 0.33 \\
\hline 16 & 9 & 7 & 49 & 5.44 \\
\hline 7 & 14 & -7 & 49 & 3.5 \\
\hline \multicolumn{7}{|c}{ Calculated Value } \\
\hline
\end{tabular}

Calculated value (15.5) is more than table value (9.488). Therefore we reject null hypothesis.

There is association between monthly income and level of satisfaction.

3. Testing the association between subject taught and satisfaction level

H0: There is no association between subject taught and level of satisfaction.

H1: There is association between subject taught and level of satisfaction.

Table 8

\begin{tabular}{|c|c|c|c|c|c|}
\hline & Science & Language & Social Science & Others & Total \\
\hline Satisfied & 6 & 9 & 5 & 3 & $\mathbf{2 3}$ \\
\hline Neutral & 9 & 11 & 5 & 2 & $\mathbf{2 7}$ \\
\hline Dissatisfied & 3 & 4 & 2 & 1 & $\mathbf{1 0}$ \\
\hline Total & $\mathbf{1 8}$ & $\mathbf{2 4}$ & $\mathbf{1 2}$ & $\mathbf{6}$ & $\mathbf{6 0}$ \\
\hline
\end{tabular}

Degree of freedom $=(\mathrm{r}-1)(\mathrm{c}-1)$

$$
=(3-1)(4-1)=6
$$

The table value at $5 \%$ level of significance for degree of freedom 6 is 12.592 .

Table 9

\begin{tabular}{|c|c|c|c|c|}
\hline $\mathbf{O}$ & $\mathbf{E}$ & $\mathbf{( O - E )}$ & $(\mathbf{O}-\mathbf{E})^{\mathbf{2}}$ & $(\mathbf{O}-\mathbf{E})^{\mathbf{2}} / \mathbf{E}$ \\
\hline 6 & 7 & 1 & 1 & .14 \\
\hline 12 & 11 & 1 & 1 & 09 \\
\hline 9 & 9 & 0 & 0 & 0 \\
\hline 15 & 15 & 0 & 0 & 0 \\
\hline 5 & 5 & 0 & 0 & 0 \\
\hline 7 & 7 & 0 & 0 & 0 \\
\hline 6 & 6 & 0 & 0 & .23 \\
\hline
\end{tabular}

Calculated value $(0.23)$ is less than table value (12.592). Therefore, we accept null hypothesis.

There is no association between subject taught and level of satisfaction.

Following are the major findings of the study:

\section{FINDINGS}

$>\quad$ Among 60 respondents selected for the study, major portion (62 percent) constitutes female and 32 percent is male.

About 40 percent of respondents are from the age group of 30-40, and only 8 percent are above 50.

$>\quad$ About 40 percent of the respondents deal with languages and only 10 percent deals with other activities such as PT, work experience, etc.

$>\quad$ Classification on the basis of monthly income reveals that 38 percent respondents earn monthly income of more than 40000, and 30 percent earn 20000 to 30000 .

$>\quad$ The study reveals that 43 percent have an experience of 3 to 5 years; whereas 25 percent have an experience of more than 5 years. 


\title{
International Advanced Research Journal in Science, Engineering and Technology
}

\author{
Vol. 8, Issue 8, August 2021
}

\section{DOI: $10.17148 /$ IARJSET.2021.8858}

$>\quad$ Looking at the qualification it is evident that 33 percent have qualified PG, B.Ed and TET, whereas only 10 percent have qualified PG, B.Ed.

$>\quad$ About 38 percent respondents are satisfied towards their job and nearly 17 percent are dissatisfied.

$>\quad$ The most important factor influencing job satisfaction is pay structure and the least important one is the approach of students towards them.

While analysing the level of satisfaction of both government, aided and unaided school teachers, it was found that government and aided school teachers are more satisfied towards salary. Government school teachers are least satisfied towards working conditions and aided school teachers towards recognition for the work done.

Unaided school teachers are more satisfied towards training and development programme and least satisfied towards salary.

$>\quad$ While examining the commitment towards institution or school, it reveals that government school teachers are very proud to tell others that they are part of their school whereas aided and unaided school teachers really care about the future and goodwill of their school.

There is association between the type of management and job satisfaction of teachers.

There is association between monthly income and level of satisfaction.

$>\quad$ There is no association between subject taught and level of satisfaction.

\section{SUGGESTIONS}

Following suggestions are made on the basis of the findings and results:

$\checkmark \quad$ Results of the study reveals that unaided school teachers are dissatisfied with salary and other benefits. The authorities should think of increasing the salary and providing more fringe benefits to the teachers. Increased salary and fringe benefits may prevent the leaving of the qualified teachers to other institutions.

$\checkmark \quad$ The administrators should recognise and appreciate the good and successful work of the teachers. If the teachers are provided with an environment where they are praised, recognised and appreciated by colleagues and principal, they may perform better and will be more committed towards their institution. Thus the management should provide such an environment to the teachers working in their school.

$\checkmark \quad$ The management should try to consider the opinions and suggestions of their staff while taking decisions which in turn will increase their level of satisfaction and commitment towards their school.

$\checkmark \quad$ The physical infrastructural facilities including better class rooms and staff rooms, library, laboratory, toilet facilities and technological aids needed to be improved especially in Government schools.

$\checkmark \quad$ The management has to treat their employees as valuable assets which will help to increase the satisfaction level of employees.

\section{CONCLUSION}

A satisfied employee is the key factor, who acts as the organisations ladder for success. Satisfaction level of the teachers with respect to different dimensions of job satisfaction such as pay structure, recognition for works, working condition etc shows significant variations among different management systems. The main factor that influence job satisfaction include pay structure, status in the society, relationship with colleagues, attitude and behaviour of management, incentives and benefits, type of management, good working environment

The commitment towards the institution depends upon the level of satisfaction. A highly satisfied employee will be more committed towards their institution than a least satisfied one. Government school teachers are satisfied towards their pay structure; but dissatisfied towards the working condition or working environment. Aided school teachers are also satisfied towards their pay structure and dissatisfied towards recognition for the work done. Unaided school teachers are more satisfied towards training and development programmes and dissatisfied towards salary provided by the management.

\section{REFERENCES}

\section{BOOKS}

- $\quad$ Kothari C. R (2011), Research Methodology, New Age International Publication.

- Spector, Paul. E (1997), Job satisfaction: Application, Assessment, Causes and consequences, Sage Publications.

- Gary Dessler (1980), Organisation theory- integrating structure and behaviour, Prentice Hall.

\section{JOURNALS}

$>\quad$ Adenike (2011), Organisational climate as a predictor of employee job satisfaction: evidence from covenant university, Business Inte

$>\quad$ lligence Journal - January, 2011 Vol.4 No.1

$>\quad$ Rasouli et al. (2011), Relationship between hardiness and job satisfaction \& stress among staff and faculty members of Islamic Azad university of Mahabad.

$>\quad$ Mehr et al. (2012), Relationship between job satisfaction and organisational culture in staffs and experts of physical education offices of Mazandaran Province, Euro. J. Exp. Bio., 2012, 2 (4):1029-1033.

$>\quad$ Kautonen \& Akola (2013), Determinants of job satisfaction for salaried and self employed professionals in Finland, The International Journal of Human Resource Management, 24(10), 2034-2053.

$>\quad$ Chahal (2013), Job Satisfaction among Bank Employees: An Analysis of the Contributing Variables towards Job Satisfaction, International Journal of Scientific \&Technology Research 2(8):11-20.

$>\quad$ Ashraf et al. (2013), The determinants of job satisfaction in public service organisation, European Journal of Scientific Research 9(35):362-

377

Shaheen (2014), job satisfaction among Male and Female Employees in Public Sector Organisations, European Journal of Business and Management, 2014 


\section{International Advanced Research Journal in Science, Engineering and Technology}

Vol. 8, Issue 8, August 2021

\section{DOI: $10.17148 / I A R J S E T .2021 .8858$}

$>\quad$ Fathima and Bhatti (2014), Job Satisfaction Among LIS Professionals of Universities in the Punjab Province, Pakistan Journal of Information Management and Libraries, 2014, vol. 15, n. 1.

$>\quad$ Adetoro (2014), Information Technology Availability, Use and Job Satisfaction of Academic Staff at Tai Solarin University of Education, Nigeria: A Correlation Study, Journal of Balkan Libraries Union 2(1):5

$>\quad$ Tabvuma et al. (2015), Orientation training and job satisfaction: A sector and gender analysis, Human Resource Management 54(2):303321. ISI: 2.474

Khan, Masrek and Nadzar (2015), Technology management competencies and job satisfaction of Pakistani University Librarians: An Empirical Assessment of Relationship, Journal of Management Research 7(2):27

$>\quad$ Snaz Aazami et. Al, (2015), The Relationship between Job Satisfaction and Psychological/Physical Health among Malaysian Working Women, The Malaysian Journal of Medical Sciences 22(4): 40-46.

$>\quad$ Sumaira and Saira Hanif (2017), Exploring the factors affecting job satisfaction of paraprofessional staff working in University Libraries of Pakistan, Human Resource Management Practices in Libraries 66(3):144-162.

$>\quad$ Yee (2018), An Analysis on the Relationship between Job Satisfaction and Work Performance among Academic Staff in Malaysian Private Universities, Journal of Arts \& Social Sciences Vol 1, Issue 2, 64-73.

$>\quad$ Ebrahim, Mustapa, Mustakim, Mokhtar and Sauid (2018), The Influence of Workplace Support on Job Satisfaction Among Academic Staff in Five Malaysian Public Research Universities, Proceedings of the Regional Conference on Science, Technology and Social Sciences : $381-389$.

WEBSITE

$\begin{array}{ll}\checkmark & \text { www.wikipedia.com } \\ \checkmark & \text { www.google.com } \\ \checkmark & \text { www.shodhganga.inflibnet.ac.in } \\ \checkmark & \text { www.scholar.google.co.in } \\ \checkmark & \text { www.academia.edu.in } \\ \checkmark & \text { www.investopedia.com }\end{array}$

